\title{
Lourdes
}

\section{Portillo: The}

Devil

Never

Sleeps

and

Other

Films 


\section{CHICANA MATTERS SERIES Deena J. González and Antonia Castañeda, editors}

Chicana Matters Series focuses on one of the largest population groups in the United States today, documenting the lives, values, philosophies, and artistry of contemporary Chicanas. Books in the series may be richly diverse, reflecting the experiences of Chicanas themselves, and incorporating a broad spectrum of topics and fields of inquiry. Cumulatively, the books represent the leading knowledge and scholarship in a significant and growing field of research and, along with the literary works, art, and activism of Chicanas, underscore their significance in the history and culture of the United States. 


\section{Lourdes}

\section{Portillo: The}

Devil

Never

Sleeps

and

Other

Films

Edited by Rosa Linda Fregoso

University of Texas Press 
Interview with Lourdes Portillo ( 1 994) was originally published in "Sacando los Trapos al Sol (Airing Dirty Laundry) in Lourdes Portillo's Melodocumystery, The Devil Never Sleeps," in Redirecting the Gaze, ed. Diana Robin and Ira Jaffe (Albany: suny Press, 1999), 307-330.

A modified version of Chapter 4 appeared in Wide Angle, vol. 20 , no. 4 (2000).

Copyright (C) 200 I by the University of Texas Press All rights reserved

Printed in the United States of America

First edition, 200 I

Requests for permission to reproduce material from this work should be sent to Permissions, University of Texas Press, P.O. Box 7819, Austin, TX 787 1 3-7819.

(2) The paper used in this book meets the minimum requirements of ANSI/NISO Z39.48-I 992 (R I 997) (Permanence of Paper).

Library of Congress Cataloging-in-Publication Data Lourdes Portillo: The devil never sleeps and other films / edited by Rosa Linda Fregoso.- - Ist ed.

p. $\quad \mathrm{cm} .-$ (Chicana matters series) Includes three interviews with Lourdes Portillo. Includes bibliographical references and index. ISBN 0-292-72524-8 (cloth : alk. paper) ISBN 0-292-72525-6 (pbk. : alk. paper)

I. Portillo, Lourdes. 2. Diablo nunca duerme.

I. Fregoso, Rosa Linda. II. Portillo, Lourdes. III. Series.

PNI 998.3.P675 L68 200I

$7^{*}$ I. $_{43} 3^{\prime} \circ 233^{\prime} \circ 92-\mathrm{dc} 2 \mathrm{I}$

00-06 I 5 I 6 
For Herman and Jasim 